ROMAN BARTNICKI, WARSZAWA

\title{
CZYM JEST PODEJŚCIE, A CZYM METODA?
}

Z satysfakcją przyjąłem recenzję książki R. Bartnicki, K. Kłósek, Metody interpretacji Nowego Testamentu. Wprowadzenie, Wydawnictwo PETRUS, Kraków 2014, napisaną przez ks. prof. Waldemara Chrostowskiego, pierwszą, jaka ukazała się po jej opublikowaniu, zamieszczoną na łamach „Collectanea Theologica” 84(2014) nr 1, s. 185-189. Po zapoznaniu się z treścią doszedłem do przekonania, że powinienem polemizować z niektórymi zawartymi w niej stwierdzeniami. Czynię to dopiero teraz, gdy opublikowane zostały także inne recenzje (w sumie osiem) i raczej nie należy się spodziewać następnych.

Autor recenzji krytykuje mój podział metod na diachroniczne i synchroniczne. Stwierdza, że w tytule paragrafu 1.2 Wybór metody (diachroniczna czy synchroniczna) (s. 12) określenie „metoda” należy zastąpić określeniem „podejście”, gdyż to w ramach podejścia diachronicznego albo synchronicznego są stosowane różne metody. Zapewniam, że odróżniam metody od podejść. Można to sprawdzić w kolejnych wydaniach mojej książki Ewangelie synoptyczne. Geneza i interpretacja, wyd. 2 w 1996 r. (s. 407-425), wyd. 3 w 2003 r. (s. 401-418) i wyd. 4 w 2012 r. (s. 417-435). „Metody” $\mathrm{i}$,podejścia" rozumiem jednak w znaczeniu zdefiniowanym w dokumencie Interpretacja Biblii w Kościele w przypisie 1 (w tekście francuskim: „Par «méthode» exégétique nous entendons un ensemble de procédés scientifiques mis en oeuvre pour expliquer les textes. Nous parlons d'«approche», lorsqu'il s'agit d'une recherche orientée selon un point de vue particulier"). Ta dość enigmatyczna definicja jest zastosowana w praktyce w ten sposób, że w dokumencie Papieskiej Komisji Biblijnej omówione są najpierw metody, a następnie podejścia. Do metod zaliczona została tylko metoda historyczno-krytyczna oraz metody analizy literackiej (analiza retoryczna, analiza narracyjna, analiza semiotyczna). Inne sposoby podchodzenia do tekstu biblijnego zostały zaliczone do ,podejść”.

Dokument Interpretacja Biblii w Kościele mówi o metodzie historyczno-krytycznej, która w aktualnym stadium rozwoju ma kilka etapów, takich jak krytyka tekstu, analiza lingwistyczna (morfologia i składnia) oraz 
semantyczna, krytyka literacka, krytyka rodzajów, krytyka tradycji, krytyka redakcji, ewentualnie funkcja pragmatyczna oraz krytyka historyczna. Te „etapy” w niektórych metodologiach nazywane są „metodami”. Przykładowo, Heinrich Zimmermann w podtytule swojej książki użył sformułowania Darstellung der historisch-kritischen Methode ${ }^{1}$ (Prezentacja metody historyczno-krytycznej), ale kolejne rozdziały poświęca metodom: Die textkritische Methode (Metoda krytyki tekstu), Die literarkritische Methode (Metoda krytyki literackiej), Die formgeschichtliche Methode (Metoda historii form), Die redaktionsgeschichtliche Methode (Metoda historii redakcji). Natomiast Jakub Slawik opisuje kolejno metody: ${ }^{2}$ Krytyka tekstu, Krytyka literacka, Morfokrytyka, Historia tradycji, Historia redakcji.

Wydaje się, że jest oczywiste, co oznacza diachronia i synchronia. Dokument Papieskiej Komisji Biblijnej stwierdza: „Podczas gdy poprzednie etapy starały się wyjaśnić tekst przez jego pochodzenie, w p e r s pektywie diachronicznej, ostatni etap kończy się studium sync h r o n i c z n y m: tekst zostaje objaśniony sam w sobie, dzięki wzajemnym relacjom różnych elementów i z rozważeniem go w aspekcie orędzia komunikowanego przez autora jego współczesnym” (I.A.3). Nieco później w dokumencie mowa jest o ,analizie synchronicznej, studium diachronicznym, egzegezie synchronicznej, sposobie diachronicznym” (I.A.4).

Ksiądz prof. W. Chrostowski w artykule z 2008 r. ${ }^{3}$ użył określeń „podejście diachroniczne” i „podejście synchroniczne”. Można w nich dostrzec pewną logikę, ale obawiam się, że wprowadzają również zamieszanie. Owszem, także dokument Papieskiej Komisji Biblijnej stosuje to określenie przy omawianiu analizy narracyjnej (I.B.2): „Son approche synchronique des textes demande à être complétée par des études diachronique” - „Jej podejście synchroniczne do tekstów musi być uzupełnione przez studia diachroniczne”. Aby jednak uniknąć zamieszania (bo „podejściami” dokument PKB nazywa sposoby podchodzenia do tekstu, których nie uważa za metody), zamiast „podejścia synchronicznego” (approche synchronique) lepiej chyba jest stosować takie określenia jak „,perspektywa diachroniczna”

$1 \quad$ H. Z i m m e r m a n n, Neutestamentliche Methodenlehre. Darstellung der historisch-kritischen Methode, neubearbeitet von K. Kliesch, Stuttgart 19827.

2 J. S 1 a w i k, Egzegeza Starego Testamentu. Wprowadzenie do metod egzegetycznych, Warszawa b.r.w.

3 W. C h r o s t o w s k i, Zarys metodologii biblistyki Nowego Testamentu, Studia Nauk Teologicznych PAN 2/2007, s. 27-46. 
(perspective diachronique) lub „synchroniczna”, albo „sposób diachroniczny” (façon surtout diachronique) i „synchroniczny” albo też „ujęcie diachroniczne i synchroniczne". Najbardziej zaś podoba mi się określenie Wilhelma Eggera i Petera Wicka: ${ }^{4}$ Lektüre unter synchronem Aspekt (,Lektura w aspekcie synchronicznym") i Lektüre unter diachronem Aspekt („Lektura w aspekcie diachronicznym”). W każdym razie metoda historyczno-krytyczna tym się różni od metod analizy literackiej, że jest głównie diachroniczna, podczas gdy te drugie są synchroniczne.

Można przy tym zauważyć, że dokument Papieskiej Komisji Biblijnej, opisując metodę historyczno-krytyczną i jej kolejne etapy, po krytyce tekstu umieszcza analizę lingwistyczną i semantyczną, a więc aspekt synchroniczny, zaś później stwierdza, że „ostatni etap kończy się studium synchronicznym". Zatem w ramach metody historyczno-krytycznej dopuszczone są także badania o charakterze synchronicznym. Współczesne metodologie wręcz tego się domagają. Podręcznik Wilhelma Eggera od pierwszego wydania w 1987 r. po szóste, na nowo opracowane przez Petera Wicka, wydane w 2011 r., po wstępnych krokach analizy (krytyka tekstu, pierwsza orientacja w tekście, m.in. odgraniczenie tekstu i podział tekstu, związek tekstu z kontekstem, tłumaczenie tekstu z wykorzystaniem innych tłumaczeń), przewiduje lekturę w aspekcie synchronicznym (analiza językowo-syntaktyczna, analiza semantyczna, analiza pragmatyczna), a następnie lekturę $\mathrm{w}$ aspekcie diachronicznym (krytyka literacka, krytyka tradycji, krytyka redakcji). Metodologia Martina Ebnera i Bernharda Heiningera ${ }^{5}$ zawiera dziesięć merytorycznych paragrafów. § 1: Ukonstytuowanie tekstu: krytyka tekstu; § 2: Opisanie tekstu: analiza językowa. W tym paragrafie przedstawiona jest analiza story (rekonstrukcja następstwa wydarzeń, analiza działających osób), analiza tekstu (postępowanie narratologiczne, postępowanie lingwistyczne), analiza narracji (podmioty i przedmioty opowiadania). § 3: Porównanie synoptyczne; § 4: Krytyka literacka; § 5: Gatunek; § 6: Typowa sytuacja zastosowania: Sitz im Leben; § 7: Tto ideowe i spoleczne: historia czasów, krytyka tradycji, historia religii; § 8: Punkt wyjścia: Wsteczne pytanie o Jezusa (= kryteria pochodzenia od Jezusa); § 9: Gmina przy pracy: historia przekazywania; § 10: Teologiczna relektura:

4 W. E g g e r, P. W i c k, Methodenlehre zum Neuen Testament, Freiburg-Basel-Wien 20116.

5 N. E b n e r, B. H e i n in g e r, Exegese des Neuen Testaments, Paderborn-München-Wien-Zürich 2005. 
historia redakcji. Wpisując się w nurt tych metodologii także ja uwzględniłem synchroniczną i diachroniczną perspektywę tekstów.

Reasumując, proponuję używać terminu „podejście” zgodnie z dokumentem Interpretacja Biblii w Kościele. Aby wyrazić sposób podchodzenia do tekstu, używajmy określeń „,aspekt” (diachroniczny lub synchroniczny) albo ,perspektywa” (diachroniczna lub synchroniczna).

Czytając drugi akapit recenzji, można odnieść wrażenie, że książka jest owocem pracy wielu współpracowników. Otóż ma ona dwóch autorów: jestem autorem tekstu na stronicach 5-200 i 245-277, a Kinga Kłósek na stronicach 201-243 i 278-284. Ksiądz prof. W. Chrostowski słusznie zauważa, że Kinga Kłósek nie nawiązała do rozdziału VII z części pierwszej, który dotyczył tej samej problematyki. Jednak na początku rozdz. VII zapowiedziałem opracowanie jej autorstwa, a więc są ze sobą powiązane.

Wbrew uwadze ks. prof. W Chrostowskiego, publikacja książki ks. Stefana Szymika Współczesne modele egzegezy biblijnej zbiegła się w czasie $\mathrm{z}$ drukiem opracowania Metody interpretacji Nowego Testamentu. Wprowadzenie. Obie książki były prezentowane jako nowości i rozprowadzane we wrześniu 2013 r. podczas Sympozjum Biblistów Polskich w Toruniu. Z powodów wydawniczo-marketingowych na rewersie strony tytułowej pracy R. Bartnickiego i K. Kłósek jako czas wydania podano jednak rok 2014. 